\title{
Correction to: America's Marine Highway stakeholders: a system-scale analysis of influence in decision-making
}

\author{
Amit J. Mokashi ${ }^{1} \cdot$ Austin Becker $^{2} \cdot$ James J. Corbett $^{3}$ \\ Published online: 2 September 2020 \\ (C) The Author(s) 2020
}

\section{Correction to: WMU J Marit Affairs \\ https://doi.org/10.1007/s13437-020-00212-0}

The article "America's Marine Highway stakeholders: a system-scale analysis of influence in decision-making" written by Amit J. Mokashi, Austin Becker, and James J. Corbett, was originally published electronically on the publisher's internet portal on July 24, 2020, without open access. With the author(s)' decision to opt for Open Choice the for Open Choice, the copyright of the article changed on August 5, 2020 to @. The Authors 2020 and the article are forthwith distributed under a Creative Commons Attribution.

Open Access This article is licensed under a Creative Commons Attribution 4.0 International License, which permits use, sharing, adaptation, distribution and reproduction in any medium or format, as long as you give appropriate credit to the original author(s) and the source, provide a link to the Creative Commons licence, and indicate if changes were made. The images or other third party material in this article are included in the article's Creative Commons licence, unless indicated otherwise in a credit line to the material. If material is not included in the article's Creative Commons licence and your intended use is not permitted by statutory regulation or exceeds the permitted use, you will need to obtain permission directly from the copyright holder. To view a copy of this licence, visit http://creativecommons.org/licenses/by/4.0/.

Publisher's note Springer Nature remains neutral with regard to jurisdictional claims in published maps and institutional affiliations.

The online version of the original article can be found at https://doi.org/10.1007/s13437-020-00212-0

Amit J. Mokashi

amokashi@njcu.edu

1 School of Business, New Jersey City University, Jersey City, NJ, USA

2 Department of Marine Affairs, University of Rhode Island, Kingston, NY, USA

3 College of Earth, Ocean, and Environment, University of Delaware, Newark, NY, USA 